\title{
PENGARUH PELATIHAN PLYOMETRIC TERHADAP DAYA LEDAK OTOT TUNGKAI DAN HASIL JARAK LOMPATAN START RENANG
}

\author{
Suratno ${ }^{1}$, I Wayan Artanayasa ${ }^{2}$, Suratmin ${ }^{3}$ \\ ${ }^{1}$ Program Studi Pendidikan Olahraga, Pascasarjana Universitas Pendidikan Ganesha \\ Singaraja, Indonesia \\ ${ }^{2}$ Program Penjaskesrek, Pascasarjana Universitas Pendidikan Ganesha \\ Singaraja, Indonesia \\ ${ }^{3}$ Program Pendidikan Olahraga, Pascasarjana Universitas Pendidikan Ganesha \\ Singaraja, Indonesia \\ e-mail: suratno@undiksha.ac.id, wayan.artanayasa@undiksha.ac.id, \\ suratmin@undiksha.ac.id
}

\begin{abstract}
Abstrak
Pembinaan ekstrakurikuler cabang olahraga renang di SMA Negeri 2 Kuta belum menunjukkan prestasi yang memuaskan, sehingga pelatih menerapkan dua metode pelatihan untuk meningkatkan kemampuan start atletnya. Penelitian ini bertujuan untuk mengkaji dan membuktikan apakah terdapat perbedaan daya ledak otot tungkai dan hasil jarak lompatan start renang antara kelompok peserta didik yang mengikuti pelatihan plyometric reaction box jump dan plyometric stair jump. Jenis penelitian ini adalah eksperimen semu dengan melibatkan 42 peserta ekstrakurikuler renang yang diambil dengan teknik ordinal pairing. Metode pengumpulan data dilakukan dengan tes dan pengukuran yang dilaksanakan selama 8 minggu serta terbagi dalam tiga kegiatan diantaranya tes awal, perlakuan, dan tes akhir. Hasil penelitian ini menunjukkan bahwa terdapat perbedaan (1) daya ledak otot tungkai dan hasil jarak lompatan start renang, (2) daya ledak otot tungkai, (3) hasil jarak lompatan start renang antara kelompok yang mengikuti pelatihan plyometric reaction box jump dan kelompok yang mengikuti pelatihan plyometric stair jump.
\end{abstract}

Kata-kata kunci: plyometric; kekuatan otot; renang.

\begin{abstract}
The extracurricular development of swimming sports at SMA Negeri 2 Kuta has not shown satisfactory performance, thus the coach applied two training methods to improve the athletes' starting abilities. This study aims to examine and prove whether there are differences in leg muscle explosive power and the results of the swimming start jump distance between groups of students participating in the plyometric reaction box jump and plyometric stair jump training. This type of research is a quasi-experimental involving 42 swimming extracurricular participants taken using the ordinal pairing technique. The data collection method was carried out by tests and measurements carried out for 8 weeks and divided into three activities including pre-tests, treatment, and post-tests. The results of this study indicate that there are differences in (1) the explosive power of the leg muscles and the results of the swimming start jump distance, (2) the explosive power of the leg muscles, (3) the results of the swimming start jump distance between the group that participated in the plyometric reaction box jump training and the group that participated in the training. stair jump plyometric training.
\end{abstract}

Keywords: plyometric; power; swimming

\section{PENDAHULUAN}

Olahraga renang saat ini telah mendapatkan tempat yang baik di hati masyarakat Indonesia. Hal ini terbukti kompetensi dasar renang telah masuk ke dalam kurikulum pembelajaran Pendidikan Jasmani Olahraga dan Kesehatan (PJOK) meskipun kompetensi dasar renang masuk ke kelompok pembelajaran II atau $B$, yang berarti pelaksanaan dapat 
diajarkan apabila ada fasilitas yang mendukungnya. Selanjutnya, Peraturan Menteri Pendidikan Nomor 62 tahun 2014 yang mengatur khusus program pengembangan diri peserta didiknya dalam bentuk ektrakurikuler di setiap satuan pendidikan (sekolah) menambah kuatnya kompetensi ekstrakurikuler cabang renang untuk diperkenalkan, berkembang, sebagai ajang penyaluran pengembangan diri, hobi, bakat peserta didik.

Pelaksanaan program ekstrakurikuler cabang olahraga renang di SMA Negeri 2 Kuta sudah tercatat dan terlaksanakan sejak berdirinya sekolah. Alasan peserta didik dalam mengikuti kegiatan ekstrakurikuler cabang olahraga renang dengan berbagai alasan, diantaranya ingin menambah keterampilan renang, menyalurkan hobi, menambah tinggi badan, mengusir kejenuhan, mau melanjutkan karir di TNI/POLRI, mengembangkan prestasi, ikut-ikutan teman, dan lain-lain. Namun hingga saat ini cabang olahraga renang oleh sekolah kami belum dipandang sebagai cabang yang mampu menyumbang medali di setiap ajang perlombaan dan hanya sebatas rutinitas pengembangan diri peserta didik saja. Sehingga dalam perjalannya belumlah mendapatkan perhatian yang khusus dan lebih baik dari sebelumnya.

Cabang olahraga renang merupakan salah satu ola raga prestasi. Olahraga prestasi merupakan kegiatan olahraga yang dilakukan dan dikelola secara profesional dengan tujuan untuk memperoleh prestasi optimal pada cabang-cabang olahraga. Atlet yang menekuni salah satu cabang tertentu untuk meraih prestasi pada tingkat daerah, nasional, maupun internasional mempunyai syarat memiliki tingkat kebugaran dan keterampilan di atas rata-rata non-atle tertulis didalam buku (Irwanto, 2016:34)

Seperti yang tercantum pada UU Nomor 3 Tahun 2005 Tentang Sistem Keolahragaan Nasional (INDONESIA, 2007), olahraga prestasi adalah olahraga yang membina dan mengembangkan olahragawan secara terencana, berjenjang, dan berkelanjutan, melalui kompetisi untuk mencapai prestasi dengan dukungan ilmu pengetahuan dan teknologi keolahragaan. Ketika renang telah ditetapkan sebagai olahraga prestasi, maka banyak faktor yang akan mempengaruhi prestasi olahraga tersebut. Sukses atau tidaknya seorang pelatih dalam mempersiapkan atlet tidak bisa dipisahkan dari kemampuan pelatih dalam menyusun, mempersiapkan, serta menyajikan program latihan kepada setiap atlet yang dibinannya. Pelatih akan tertolong apabila saat mempersiapkan atlet, telah menyusun program latihan dengan lebih terinci yang sesuai dengan asas-asas ilmu melatih modern. Para atlet pelajar ekstrakurikuler renang yang telah memilih jalur prestasi di SMA Negeri 2 Kuta dituntut mempunyai target puncak penampilannya (peak performence) sebagai ajang aktualisasi dalam mengikuti latihan selama ini, yaitu di ajang Pekan Olahraga Pelajar (PORJAR) tingkat Kabuputen Badung.

Namun pembinaan ekstrakurikuler cabang olahraga renang di SMA Negeri 2 Kuta belum menunjukkan prestasi yang memuaskan bahkan cenderung menurun tiap tahunnya. Hal ini dapat dilihat dalam perolehan medali tahun 2018 memperoleh peringkat 4 dari 17 tingkat SMA/SMK, setahun berikutnya menduduki peringkat 6 dari 17 tingkat SMA/SMK, sedangkan tahun 2020 peringkat 9 dari 17 tingkat SMA/SMK dalam PORJAR Kabupaten Badung. Pihak sekolah dan pelatih telah memikirkan untuk meningkatkan prestasi cabang olahraga renang dan memetakan cabang olahraga renang sebagai salah satu cabang olahraga penyumbang medali untuk meraih juara umum, karena dengan pemikiran satu atlet dapat menyumbangkan 3 medali dalam kegiatan PORJAR.

Dalam cabang olahraga renang ada 4 gaya renang yang dilombakan, yaitu: gaya bebas, gaya punggung, gaya dada, dan gaya kupu-kupu. Pendapat dari (Irwanto, 2016) menyatakan bahwa "Swimming performence in short distence swimming even is measured by the sumk of the time of four primary components; the start, the swim, the trun, and the finish", yang dapat diartikan bebas ke dalam Bahasa Indonesianya, "pada perlombaan renang jarak pendek terdapat empat komponen yang harus dilakukaan oleh setiap perenaang, yaitu start, berenang, pembalikan, dan finish". Dalam mengikuti perlombaan renang seorang perenang tidak hanya mengandalkan kemampuan teknik gerakan renangan semata, tetapi si perenang juga harus menguasai teknik start renang yang baik dan benar, khususnya di nomor-nomor pendek 
(sprint), atlet pelajar SMA Negeri 2 Kuta dalam keikutsertaan perlombaan di ajang PORJAR selalu mengikuti nomor-nomor pendek sebagai nomor pilihannya. Dimana secara teori dalam pelaksanan lomba nomor sprint harus fokus dan tidak boleh salah sedikitpun dari 4 komponen yang telah disinggung di atas, karena dengan kesalahan sedikit pada salah satu komponen saja akan mempengaruhi hasil yang dicapai oleh si atlet (personal best time).

Dalam penelitian ini peneliti fokus pada komponen start. Start adalah salah satu komponen dalam perlombaan renang, dan sebagai senjata awal buat perenang dalam meraih prestasi optimal, untuk mencapai prestasi yang maksimal dalam perlombaan renang, perenang tidak hanya memerlukan kemampuan berenang saja tetapi juga kemampuan menguasai teknik start yang baik dan benar. Secara teoritis dan peraturan perlombaan, start terbagi menjadi dua yaitu start atas dan start bawah. Start atas dilakukan di atas balok start digunakan untuk gaya bebas, gaya kupu, dan gaya dada. Sedangkan start bawah adalah start yang dilakukan di air di bawah balok start digunakan oleh gaya punggung.

Teknik start dalam olahraga renang yang biasa digunakan oleh perenang adalah grab start dan track start. Sedangkan start bila dianalisis gerakannya ada tiga fase yaitu; fase di atas balok start (on-block), fase tubuh terbang di udara (fly), dan fase gerakan di bawah air (under water), dan dalam penelitian yang diadakan oleh peneliti tidak akan memaksakan atlet pelajar menggunakan salah satu jenis start yang ada. Dasar pemikiranya peneliti dan atas anjuran beberapa pakar dalam renang adalah, start merupakan senjata awal dalam mengikuti suatu lomba yang telah dikembangakan dan dilatih oleh atlet selama ini, maka biarkan atlet menggunakan keterampilan yang selama ini dikuasai, dilatih, dan diyakini selama ini tanpa adanya arahan dan paksaan.

Munculnya masalah pada atlet pelajar di SMA Negeri 2 Kuta terjadi karena ketidaktahuan di dalam melakukan gerak teknik start yang baik dan benar. Hal ini dikarenakan kekurangan informasi tentang teknik/teori start, dan tidak didukung oleh kondisi fisik khusunya daya ledak ektremitas bawah berupa otot tungkai. Kendala di atas ditambah dengan kebiasaan saat berlatih tidak didukung oleh sarana kolam renang yang tidak standar (50 meter), start block yang tidak standar, pemaksaan terhadap suatu teknik start yang tidak diinginkan/tidak disukai, hingga faktor mental. semua akan berimbas pada pernampilan atlet dalam pelaksanaan lomba, sehingga saat melakukan start terlihat penuh keraguan, tidak menghasilkan gerakan yang power full, hal ini tentu saja merugikan penampilan atlet.

Dalam melaksanakan teknik start renang, sumbangan otot ektremitas bagian bawah dalam bentuk hentakan atau dorongan (power) otot tungkai saat melakukan start perlu dilakukan dengan gerakan yang cepat dan kuat guna menghasilkan jarak tolakan start yang maksimal, namun di sinilah salah satu titik kelemahan atlet renang SMA Negeri 2 Kuta saat pelaksanaan start masih lemah, karena tidak didukung dengan kondisi fisik yang baik. Khususnya tidak dapat mengembangkan atau memaksimalkan daya ledak otot tungkai dalam memberikan pengaruh pada pelaksanaan start.

Kemampuan otot-otot tungkai dapat menghasilkan kecepatan, kekuatan, daya ledak, dan daya tahan. Atlet dapat melakukan gerakan yang lebih efisien, apabila ditunjang dengan power otot tungkai yang besar. Untuk itu peneliti dan sebagai pembina ekstrakurikuler cabang renang perlu memberikan pelatihan darat (dry land) dalam bentuk pelatihan plyometric guna menunjang daya ledak otot tungkai saat atlet melakukan teknik start dalam olahraga renang.

Pembina ekstrakurikuler cabang renang di SMA Negeri 2 Kuta perlu mengamati, mengevaluasi, dan memutuskan akan mengganti program latihan darat (dry land) yang selama ini diberikan kepada atletnya (metode konvensional). Dalam penelitian ini peneliti akan memberikan pelatihan plyometric reaction box jump dan pelatihan plyometric stair jump. Kedua metode pelatihan ini dipandang oleh peneliti dan didukung berdasarkan teori dapat meningkatkan program peningkatan kondisi fisik ekstremitas bawah berupa (power) pada otot tungkai sehingga dapat memberikan pengaruh pada hasil jarak lompatan start. Sehingga kelemahan dan kekhawatiran pelatih terhadap penampilan atletnya terjawab.

Menurut paparan permasalahan dan evaluasi yang dihadapi oleh pelatih ekstrakurikuler renang di SMA Negeri 2 Kuta untuk meningkatkan performa atletnya dalam melakukan start 
adalah dengan memberikan pelatihan plyometric reaction box jump dan plyometric stair jump. Dua metode pelatihan tersebut dapat meningkatkan kondisi fisik seorang atlet khususnya dalam hal daya ledak (power) otot tungkai. Dari hasil pengamatan kebanyakan atlet belum mampu menggunakan start sebagai senjata awal untuk mengikuti lomba renang, karena atlet kurang optimal dalam penggunaan daya ledak otot tungkainya (PRAMONO, 2014).

Peneliti di sini akan memberikan pelatihan darat (dry land) kepada atlet ekstrakurikuler renang di SMA Negeri 2 Kuta dan memfokuskan pada peningkatan kondisi fisik memberikan pelatihan plyometric reaction box jump dan plyometric stair jump. Oleh karena itu komponen biomotor yang dibutuhkan untuk mendukung daya ledak otot tungkai dalam pelaksanaan teknik grab start dan track start, peneliti memberikan kedua latihan tersebut, karena peneliti beranggapan kedua metode pelatihan tersebut merupakan bentuk pelatihan yang dapat meningkatkan power otot tungkai yang kemiripan gerakan pelaksanaannya mirip dengan abaaba start, yang pada awalnya kita hanya memberikan pelatihan static front box jump tanpa ada aba-aba dalam dalam pelaksanaanya.

Sedangkan pelatihan stair jump dapat membantu membangkitkan daya ledak otot tungkai secara landai, bertahap, dan menantang. Pada awalnya kita memberikan pelatihan squat jump yang hanya statis pergerakanya di tempat saja. Pelatihan reaction box jump dan pelatihan stair jump dari sarana dan prasarana kedua metode pelatihan tersebut telah tersedia di areal latihan, di lingkungan rumah, dan lingkungan sekolah. Setidaknya pelatih telah memanfaatkan prasaran dan sarana yang ada di lingkungan kita, memberikan alternatif dan variasi dalam pemberian program pembentukan kondisi fisik khususnya daya ledak otot tungkai.

Berdasarkan uraian latar belakang permasalahan di atas, pengamatan, dan pengalaman di lapangan, dalam rangka meningkatkan kondisi fisik dalam mencapai sasaran yang telah ditetapkan dalam program pelatihan darat, khususnya otot tungkai perenang sangat berperan memberi pengaruh terhadap jauhnya lompatan saat melakukan start. Berdasarkan ketertarikan peneliti untuk melakukan penelitian ini, maka peneliti akan mengadakan penelitian dengan judul "Pengaruh Pelatihan Plyometric terhadap Daya Ledak Otot Tungkai dan Hasil Jarak Lompatan Start Renang".

\section{METODE}

Rancangan penelitian yang digunakan dalam penelitian ini adalah eksperimen semu (quasi experimental) (Sugiyono \& Kuantitatif, 2009). Sampel yang dalam penelitian ini adalah seluruh peserta didik SMA Negeri 2 Kuta yang mengikuti ekstrakurikuler renang tahun pelajaran 2020/2021 yang terdiri dari 31 orang putra dan 11 orang putri. Kriteria sampel yaitu: 1) memiliki kemampuan berenang 50 meter, 2) kemampuan melakukan start, 3) berjenis kelamin putra/putri, dan 4) mendapat ijin dari orangtua peserta didik dalam mengikuti penelitian ini.

Penelitian ini diawali dengan melakukan pre-test, dan dilanjutkan dengan perlakuan selama 8 minggu dengan durasi waktu 90 menit yang dilaksanakan pada pukul $15.00-16.30$ WITA. Selanjutnya, instrumen penelitian ini berupa tes praktik lompatan vertical jump $M D$, tes jauhnya lompatan pada start renang. Kemudian hasil tes awal dan tes akhir digunakan untuk menentukan prestasi atlet.

Selanjutnya metode analisis data yang digunakan adalah uji Manova. Namun, sebelumnya dilakukan uji normalitas dengan uji Kolmogorov-smirnov dan homogenitas dengan uji Levene pada taraf signifikansi ( $\alpha$ ) 0,05. Kriteria pengambilan keputusan jika nilai signifikansi lebih besar dari pada a (sig $>\alpha$ ), maka dapat disimpulkan data berdistribusi normal dan begitupula untuk uji homogentiasnya (Kanca, 2010). Penelitian ini mengajukan tiga hipotesis yakni; 1) terdapat pengaruh pelatihan plyometric reaction box jump terhadap daya ledak otot tungkai dalam pencapaian jarak lompatan start pada cabang olahraga renang pada peserta didik ekstrakurikuler renang SMA Negeri 2 Kuta, 2) terdapat pengaruh pelatihan plyometric stair jump terhadap daya ledak otot tungkai dalam pencapaian jarak lompatan start pada cabang olahraga renang pada peserta didik ekstrakurikuler renang SMA Negeri 2 Kuta, dan 3) 
terdapat pengaruh sumbangan secara bersama-sama pelatihan plyometric reaction box jump dan pelatihan plyometric stair jump terhadap daya ledak otot tungkai dalam jarak lompatan start pada cabang olahraga renang pada peserta didik ekstrakurikuler renang SMA Negeri 2 Kuta. Untuk menguji hipotesis pertama dan kedua menggunakan uji ANAVA satu jalur.

\section{HASIL DAN PEMBAHASAN}

Paparan hasil penelitian ini dimulai dengan hasil uji normalitas untuk daya ledak otot tungkai dan hasil jarak lompatan start renang ditunjukkan pada Tabel 1 di bawah.

Tabel 1. Ringkasan Uji Normalitas DLOT dan HJLSR

\begin{tabular}{llrrrrrr}
\hline & & \multicolumn{3}{c}{ Kolmogorov-Smirnov } & \multicolumn{3}{c}{ Shapiro-Wilk } \\
& & Statistic & df & \multicolumn{1}{c}{ Sig. } & Statistic & df & Sig. \\
\hline DLOT & PRBJ & 0,166 & 21 & 0,133 & 0,950 & 21 & 0,343 \\
& PSJ & 0,165 & 21 & 0,140 & 0,932 & 21 & 0,149 \\
HJLSR & PRBJ & 0,134 & 21 & $0,200^{*}$ & 0,944 & 21 & 0,265 \\
& PSJ & 0,129 & 21 & $0,200^{*}$ & 0,967 & 21 & 0,667 \\
\hline
\end{tabular}

Dari Tabel 1 di atas diketahui bahwa untuk data daya ledak otot tungkai dan jarak lompatan start renang dengan metode Plyometric Reaction Box Jump dan Plyometric Stair Jump nilai signifikansinya berada di atas 0,05 maka dapat disimpulkan bahwa data berdistribusi normal. Selanjutnya, hasil uji homegenitas varian covarian terangkum pada Tabel 2 di bawah.

Tabel 2. Hasil Uji Homogentas Matriks Varian Covarian

\begin{tabular}{cc}
\hline Box's M & 6,943 \\
F & 2,189 \\
Df & 3 \\
Sig. & 0,087 \\
\hline
\end{tabular}

Berdasarkan hasil yang terangkum pada Tabel 2, diperoleh nilai sig. sebesar 0,087 yang lebih besar dari nilai signifikansi $5 \%$, sehingga dapat disimpulkan matriks varians antar variabel daya ledak otot tungkaidan hasil jarak lompatan start renang siswa adalah sama (homogen).

Tabel 3. Ringkasan Uji Manova

\begin{tabular}{|c|c|c|c|c|c|c|}
\hline \multirow{2}{*}{\multicolumn{2}{|c|}{ Effect }} & \multicolumn{5}{|c|}{ Hypothesis } \\
\hline & & Value & $\mathrm{F}$ & $d f$ & Error $d f$ & Sig. \\
\hline \multirow[t]{4}{*}{ Intercept } & Pillai's Trace & 0,983 & $1096,066^{b}$ & 2,000 & 39,000 & 0,000 \\
\hline & Wilks' Lambda & 0,017 & $1096,066^{b}$ & 2,000 & 39,000 & 0,000 \\
\hline & Hotelling's Trace & 56,209 & $1096,066^{b}$ & 2,000 & 39,000 & 0,000 \\
\hline & $\begin{array}{l}\text { Roy's Largest } \\
\text { Root }\end{array}$ & 56,209 & $1096,066^{b}$ & 2,000 & 39,000 & 0,000 \\
\hline \multirow[t]{4}{*}{ MP } & Pillai's Trace & 0,887 & $153,167^{b}$ & 2,000 & 39,000 & 0,000 \\
\hline & Wilks' Lambda & 0,113 & $153,167^{b}$ & 2,000 & 39,000 & 0,000 \\
\hline & Hotelling's Trace & 7,855 & $153,167^{b}$ & 2,000 & 39,000 & 0,000 \\
\hline & $\begin{array}{l}\text { Roy's Largest } \\
\text { Root }\end{array}$ & 7,855 & $153,167^{b}$ & 2,000 & 39,000 & 0,000 \\
\hline
\end{tabular}


Berdasarkan Tabel 3. diketahui bahwa taraf signifikansi untuk Pillai's Trace, Wilks' Lambda, Hotelling's Trace, dan Roy's Largest Root masing-masing dengan F = 153,167 dan nilai signifikansi semuanya lebih kecil dari $0,05(p<0,05)$. Jadi, dapat disimpulkan bahwa terdapat pengaruh yang signifikan $(p<0,05)$ variabel mtode-metode pelatihan plyometric terhadap variabel daya ledak otot tungkai dan hasil jarak lompatan start renang siswa

Tabel 4. Ringkasan Test of Between-Subjects Effect

\begin{tabular}{|c|c|c|c|c|c|c|}
\hline Source & $\begin{array}{l}\text { Dependent } \\
\text { Variable }\end{array}$ & $\begin{array}{c}\text { Type III Sum of } \\
\text { Squares }\end{array}$ & $d f$ & $\begin{array}{l}\text { Mean } \\
\text { Square }\end{array}$ & $\mathrm{F}$ & Sig. \\
\hline \multirow{2}{*}{$\begin{array}{l}\text { Corrected } \\
\text { Metode }\end{array}$} & DLOT & $228,667^{a}$ & 1 & 228,667 & 71,193 & 0,000 \\
\hline & HJLSR & $0,491^{b}$ & 1 & 0,491 & 278,799 & 0,000 \\
\hline \multirow[t]{2}{*}{ Intercept } & DLOT & 4950,857 & 1 & 4950,857 & 1541,40 & 0,000 \\
\hline & HJLSR & 1,835 & 1 & 1,835 & $\begin{array}{r}1042,72 \\
1\end{array}$ & 0,000 \\
\hline \multirow[t]{2}{*}{ MP } & DLOT & 228,667 & 1 & 228,667 & 71,193 & 0,000 \\
\hline & HJLSR & 0,491 & 1 & 0,491 & 278,799 & 0,000 \\
\hline \multirow[t]{2}{*}{ Error } & DLOT & 128,476 & 40 & 3,212 & & \\
\hline & HJLSR & 0,070 & 40 & 0,002 & & \\
\hline \multirow[t]{2}{*}{ Total } & DLOT & 5308,000 & 42 & & & \\
\hline & HJLSR & 2,397 & 42 & & & \\
\hline \multirow[t]{2}{*}{$\begin{array}{l}\text { Corrected } \\
\text { Total }\end{array}$} & DLOT & 357,143 & 41 & & & \\
\hline & HJLSR & 0,561 & 41 & & & \\
\hline
\end{tabular}

Berdasarkan Tabel 4. diperoleh hasil perhitungan MANOVA nilai-nilai statistik Pillai's Trace,Wilk's Lambda, Hotelling's Trace, dan Roy'sLargest Root masing-masing dengan F = 71,193 dan $\mathrm{p}<0,05$. Dengan demikian, dapat diambil keputusan untuk hipotesis yang kedua sebagai berikut; 1 ) terdapat perbedaan daya ledak otot tungkai yang signifikan antara peserta didik yang mengikuti ekstrakurekuler cabang renang dengan pelatihan plyometric reaction box jump dan pelatihan plyometric stair jump. 2) terdapat perbedaan hasil jarak lompatan start renang yang signifikan antara peserta didik yang mengikuti ekstrakurekuler cabang renang dengan pelatihan plyometric reaction box jump dan pelatihan plyometric stair jump.

Sebagai tindak lanjut dari pengujian hipotesis kedua dan ketiga, maka dilakukan analisis signifikansi perbedaan nilai rata-rata daya ledak otot tungkaidan hasil jarak lompatan start renang ekstrakurikuler cabang renang antara kelompok pelatihan plyometric. Nilai rata-rata terestimasi $(\mu)$ dan simpangan baku dari nilai daya ledak otot tungkai dan hasil jarak lompatan start renang ekstrakurekuler cabang renangkelompok pelatihan plyometric reaction box jump dan kelompok pelatihan plyometric stair jump disajikan pada Tabel 5 berikut.

Tabel 5. Nilai rata-rata daya ledak otottungkai dan hasil jarak lompatan start renang ekstrakurekuler cabang renang siswa terestimasi pada kelompok PRBJ dan PSJ

\begin{tabular}{lrrrrr}
\hline Variabel & & & \multicolumn{3}{c}{ Interval Konvidensi 95\% } \\
Terikat & MP & \multicolumn{1}{c}{ Mean } & Std. Error & Terendah & \multicolumn{1}{c}{ Terendah } \\
\hline Pillai's Trace & PRBJ & 13,190 & 0,391 & 12,400 & 13,981 \\
$\begin{array}{l}\text { Wilks' } \\
\text { Lambda }\end{array}$ & PSJ & 8,524 & 0,391 & 7,733 & 9,314 \\
$\begin{array}{l}\text { Hotelling's } \\
\text { Trace }\end{array}$ & PRBJ & 0,317 & 0,009 & 0,299 & 0,336 \\
$\begin{array}{l}\text { Roy's Largest } \\
\text { Root }\end{array}$ & PSJ & 0,101 & 0,009 & 0,082 & 0,119 \\
\hline
\end{tabular}


Berdasarkan nilai rata-rata dan standar deviasi daya ledak otot tungkai dan hasil jarak lompatan start renang ekstrakurekuler cabang renang siswa pada Tabel 5, dapat dianalisis signifikansi perbedaan nilai-nilai rata-rata pasangan kelompok PRBJ dan kelompok PSJ. Signifikansi perbedaan nilai rata-rata pasangan tersebut diuji dengan metode Least Significant Difference (LSD) (Santoso, 2017).

Pada taraf signifikansi $\alpha=0,05$, jumlah sampel kelompok PRBJ dan kelompok PSJ masing-masing adalah 21, jumlah sampel total $(N)$ adalah 42 , jumlah kelompok metode pembelajaran $a=2$, diperoleh nilai statistik $t_{\text {tabel }}=t_{(0,05 / 2 ; 42-2)}=t_{(0,025 ; 40)}=2,02$. Dengan menggunakan nilai $t_{\text {tabel }}$ dan $M S \varepsilon=3,212$ untuk variabel terikat daya ledak otot tungkai siswa diperoleh batas penolakan adalah $\mathrm{LSD}=1,117$. Dan untuk variabel terikat hasil jarak lompatan start renang dengan nilait $t_{\text {tabel }}=\mathrm{t}_{(0,05 / 2 ; 42-2)}=\mathrm{t}_{(0,025 ; 40)}=2,02$ dan $\mathrm{MS} \varepsilon=0,002$ diperoleh batas penolakan adalah LSD $=0,028$. Rangkuman hasil uji signifikansi perbedaan nilai rata-rata daya ledak otot tungkaidan hasil jarak lompatan start renang ekstrakurekuler cabang renang siswa antara kelompok siswa yang mengikuti pelatihan plyometric reaction box jump dan kelompok pelatihan plyometric stair jump disajikan pada Tabel 6.

Tabel 6. Signifikansi Perbedaan Nilai Rata-Rata Daya Ledak Otot Tungkai dan Hasil Jarak Lompatan Start Renang Ekstrakurekuler Cabang Renang Siswa Kelompok PRBJ dan Kelompok PSJ

\begin{tabular}{|c|c|c|c|c|c|}
\hline $\begin{array}{l}\text { Variabel } \\
\text { Terikat }\end{array}$ & (I) MP & (J) MP & $\begin{array}{l}\text { Perbedaan } \\
\text { Rata-rata } \\
(\text { (I-J) }\end{array}$ & Std. Error & Sig. \\
\hline DLOT & PRBJ & PSJ & $4,667^{*}$ & 0,553 & 0,000 \\
\hline \multirow{3}{*}{ HJLSR } & PSJ & PRBJ & $-4,667^{*}$ & 0,553 & 0,000 \\
\hline & PRBJ & PSJ & $0,216^{*}$ & 0,013 & 0,000 \\
\hline & PSJ & PRBJ & $-0,216^{*}$ & 0,013 & 0,000 \\
\hline
\end{tabular}

Berdasarkan Tabel 6, tampak perbedaan nilai rata-rata daya ledak otot tungkai ekstrakurekuler cabang renang Siswa Kelompok PRBJ dan Kelompok PSJ adalah $\Delta \mu$ $=[\mu($ PRBJ $)-\mu($ PSJ $)]=4,667$ dengan simpangan baku 0,553 dan angka signifikansi 0,000 . Angka signifikansi tersebut lebih kecil dari 0,05. Di samping itu, nilai $\Delta \mu=[\mu(\mathrm{PRBJ})-\mu(\mathrm{PSJ})]=$ 4,667 lebih besar dari LSD =1,117. Jadi, nilai rata-rata daya ledak otot tungkai ekstrakurekuler cabang renang siswa kelompok PRBJ dan PSJ berbeda secara signifikan pada taraf signifikansi 0,05.

Berdasarkan Tabel 6, tampak pula perbedaan nilai rata-rata hasil jarak lompatan start renang ekstrakurekuler cabang renang siswa kelompok PRBJ dan PSJ adalah $\Delta \mu=[\mu(\mathrm{PRBJ})$ $\mu(\mathrm{PSJ})]=0,216$ dengan simpangan baku 0,013 dan angka signifikansi 0,000 . Angka signifikansi tersebut lebih kecil dari 0,05. Di samping itu, nilai $\Delta \mu=[\mu(\mathrm{PRBJ})-\mu(\mathrm{PSJ})]=0,216$ lebih besar dari LSD $=0,028$. Jadi, nilai rata-rata hasil jarak lompatan start renang ekstrakurekuler cabang renang siswa kelompok PRBJ dan PSJ berbeda secara signifikan pada taraf signifikansi 0,05 .

Berdasarkan hasil analisis data telah terbukti bahwa terdapat perbedaan daya ledak otot tungkai yang signifikan antara peserta didik yang mengikuti ekstrakurekuler cabang renang dengan pelatihan plyometric reaction box jump dan pelatihan plyometric stair jump. Berdasarkan hasil temuan dalam penelitian ini, dapat disimpulkan bahwa pelatihan plyometric reaction box jump dan pelatihan plyometric stair jump berpengaruh terhadap daya ledak otot tungkai yang signifikan antara peserta didik yang mengikuti ekstrakurekuler cabang renang.

Berdasarkan hasil analisis data telah terbukti bahwa terdapat perbedaan hasil jarak lompatan start renang yang signifikan antara peserta didik yang mengikuti ekstrakurekuler cabang renang dengan pelatihan plyometric reaction box jump dan pelatihan plyometric stair jump. Berdasarkan hasil temuan dalam penelitian ini, dapat disimpulkan bahwa pelatihan 
plyometric reaction box jump dan pelatihan plyometric stair jump berpengaruh terhadap hasil jarak lompatan start renang yang signifikan antara peserta didik yang mengikuti ekstrakurekuler cabang renang.

Berdasarkan hasil analisis data telah terbukti bahwa terdapat perbedaan daya ledak otot tungkai dan hasil jarak lompatan start renang antara kelompok peserta didik yang mengikuti pelatihan plyometric reaction box jump dan kelompok peserta didik yang mengikuti pelatihan plyometric stair jump pada peserta didik yang mengikuti ekstrakurikuler cabang renang. Berdasarkan hasil temuan dalam penelitian ini, dapat disimpulkan bahwa pelatihan plyometricreaction box jump dan pelatihan plyometricstair jump berpengaruh terhadap daya ledak otot tungkai dan hasil jarak lompatan start renang yang signifikan antara peserta didik yang mengikuti ekstrakurekuler cabang renang sejalan dengan penelitian yang dikemukakan oleh (Suparyo, 2018) .

Berdasarkan hasil analisis data telah terbukti bahwa daya ledak otot tungkai dan hasil jarak lompatan start renang kelompok peserta didik yang mengikuti pelatihan plyometricreaction box jump lebih besar dibandingkan kelompok peserta didik yang mengikuti pelatihan plyometricstair jump pada peserta didik yang mengikuti ekstrakurikuler cabang renang. Berdasarkan hasil temuan dalam penelitian ini, dapat disimpulkan bahwa pelatihan plyometricreaction box jump lebih baik dibandingkan pelatihanplyometric stair jump pada peserta didik yang mengikuti ekstrakurekuler cabang renang. Hasil penelitian ini sejalan dengan penelitian yang dilaksanakan oleh (PRAMONO, 2014) dalam penelitiannya yang berjudul Pengaruh Latihan Plyometric terhadap Hasil Tolakan Pada Olahraga Renang, yang menyatakan bahwa terdapat pengaruh latihan plyometric terhadap hasil tolakan start dalam olahraga renang terutama pada block time phase.

Berdasarkan hasil penelitian ini menunjukkan bahwa pelatihan plyometric reaction box jump dan pelatihan plyometric stair jump dapat meningkatkan daya ledak otot tungkai yang signifikan antara peserta didik yang mengikuti ekstrakurekuler cabang renang. Maka beberapa implikasi dari hasil penelitian ini adalah (1) penggunaan pelatihan plyometricreaction box jump dan pelatihan plyometricstair jump patut menjadi perhatian dan dipertimbangkan oleh para pendidik sebagai salah satu alternatif inovasi dalam pelatihan ekstrakurekuler cabang renang, (2) peserta didik lebih antusias berlatih dengan pelatihan plyometricreaction box jump dan pelatihan plyometricstair jump, (3) penerapan pelatihan plyometricreaction box jump dan pelatihan plyometricstair jump dapat meningkatkan hasil jarak lompatan start renang yang signifikan antara peserta didik yang mengikuti ekstrakurekuler cabang renang, (4) penerapan pelatihan plyometricreaction box jump dan pelatihan plyometricstair jump dapat memotivasi peserta didik dalam melatih diri dalam mengikuti ekstrakurikuler cabang renang. Hal ini dapat dilihat dari peningkatan latihan hingga $85 \%$.

\section{SIMPULAN DAN SARAN}

\section{Simpulan}

Berdasarkan temuan-temuan yang telah diuraikan di atas, maka dapat ditarik beberapa simpulan sebagai berikut.

1. Terdapat perbedaan daya ledak otot tungkai dan hasil jarak lompatan start renang antara kelompok peserta didik yang mengikuti pelatihan plyometric reaction box jump dan kelompok peserta didik yang mengikuti pelatihan plyometric stair jump pada peserta didik yang mengikuti ekstrakurikuler cabang renang.

2. Terdapat perbedaan daya ledak otot tungkai antara kelompok peserta didik yang mengikuti pelatihan plyometric reaction box jump dan kelompok peserta didik yang mengikuti pelatihan plyometric stair jump pada peserta didik yang mengikuti ekstrakurikuler cabang renang.

3. Terdapat perbedaan hasil jarak lompatan start renang antara kelompok peserta didik yang mengikuti pelatihan plyometric reaction box jump dan kelompok peserta didik yang mengikuti pelatihan plyometric stair jump pada peserta didik yang mengikuti ekstrakurikuler cabang renang. 
4. Pelatihan plyometric reaction box jump lebih baik jika dibandingkan dengan pelatihan plyometric stair jump pada peserta didik yang mengikuti ekstrakurikuler cabang renang.

\section{Saran}

Berdasarkan temuan penelitian, serta dengan mempertimbangkan implikasi penelitian di atas ada beberapa saran yang dapat disampaikan dalam hal ini adalah: Pertama, bagi para pendidik pengampu ekstrakurikuler renang disarankan agar menggunakan pelatihan plyometric reaction box jump dan pelatihan plyometric stair jump sebagai alternatif inovasi pelatihan untuk memotivasi peserta didik dan untuk meningkatkan prestasi renang peserta didik. Kedua, kepada pendidik pengampu ekstrakurikuler renang disarankan agar dalam pelatihan tidak hanya menekankan proses pelatihan sebagai produk saja, tetapi juga menekankannya sebagai proses. Ketiga, penerapan pelatihan plyometric reaction box jump dan pelatihan plyometric stair jump mengisyaratkan peran pendidik sebagai fasilitator, sehingga peserta didik mendapat kesempatan yang seluas-luasnya dalam berprakarsa untuk mendapatkan hasil yang maksimal.

\section{DAFTAR PUSTAKA}

INDONESIA, P. R. (2007). Undang-undang Republik Indonesia Nomor 3 Tahun 2005 Tentang Sistem Keolahragaan Nasional.

Irwanto. (2016). Psikologi Umum. Gramedia Pustaka Utama.

Kanca, I. N. (2010). Metode Penelitian Pengajaran Pendidikan Jasmani dan Olahraga. Singaraja: Universitas Pendidikan Ganesha.

PRAMONO, D. B. (2014). Perbandingan Jarak Lompatan antara Grab Start dan Track Start pada Cabang Olahraga Renang (Atlet Renang SC Eagle Surabaya). Jurnal Kesehatan Olahraga, 2(1).

Santoso, S. (2017). Statistik multivariat dengan SPSS. Elex Media Komputindo.

Sugiyono, M. P. P., \& Kuantitatif, P. (2009). Kualitatif, dan R\&D, Bandung: Alfabeta. Cet. Vii.

Suparyo, S. (2018). Pengaruh Pembinaan Ekstrakurikuler dan Ketersediaan Sarana Prasarana Terhadap Pengembangan Olahraga: Studi Pada SMA Negeri Se-Kabupaten Majalengka. Indonesian Journal of Education Management \& Administration Review, 1(1), 41-54. 